\title{
Enzymatic evidence of impaired reperfusion in diabetic patients after thrombolytic therapy for acute myocardial infarction: A role for plasminogen activator inhibitor?
}

\author{
R P Gray, J S Yudkin, D L Patterson
}

\begin{abstract}
Objective-To compare the activity of plasminogen activator inhibitor (PAI-1) in diabetic and non-diabetic patients admitted with acute myocardial infarction and to determine whether PAI-1 activity influences reperfusion after thrombolytic therapy.
\end{abstract}

Design-Prospective study of patients admitted with acute myocardial infarction.

Setting-District general hospital.

Main outcome measures-Reperfusion assessed by time to peak release of creatine kinase-MB isoenzyme.

Results-Baseline PAI-1 activity and antigen concentrations were significantly higher in diabetic patients $(n=45)$ than in non-diabetic patients $(n=110)(24 \cdot 6$ (6.9) v 18:6 (7.9) AU/ml (AU = arbitrary units) $(p=0.0001)$ and $58 \cdot 8(13 \cdot 1-328 \cdot 8) v$ $41.0(10 \cdot 9-125 \cdot 4) \mathrm{ng} / \mathrm{ml}(p=0.004)$. Time to peak release of creatine kinase-MB was calculated in $123(80 \%)$ patients. In 98 who received thrombolytic therapy the median time to peak enzyme release was $15.5 \mathrm{~h}(7 \cdot 5-24 \mathrm{~h})$ in diabetic patients ( $=26)$ and $12 \mathrm{~h}(5-26 \mathrm{~h})$ in non-diabetic patients $(n=72)(p=0.005)$. In those with a time to peak release of $\leqslant 12 \mathrm{~h}$, indicating likely successful reperfusion, PAI-1 activity was $17 \cdot 5$ (7.8) AU/ml compared with $22.8(7 \cdot 7) \mathrm{AU} / \mathrm{ml}$ in those with a time to peak release of $>12 \mathrm{~h}$ ( $p=$ 0.001 ). In multiple regression analysis both diabetes $(p=0.0001)$ and PAI-1 activity at admission $(p=0.029)$ were independently related to successful reperfusion. In 13 patients with evidence of reinfarction in hospital PAI-1 activity on day 3 was $26.7(6.4)$ AU/ml compared with $21 \cdot 7(6.3) \mathrm{AU} / \mathrm{ml}$ in those without evidence of reinfarction $(p=0.032)$.

Conclusion-Both raised PAI-1 activity on admission and diabetes were associated with a reduced likelihood of enzymatic evidence of reperfusion after thrombolytic therapy. Increased PAI-1 activity on day 3 was associated with an increased risk of reinfarction. Diabetic patients had higher PAI-1 activity on admission. This may partly explain their reduced likelihood of reperfusion.

(Br Heart $\mathcal{F} 1993 ; 70: 530-536)$

Thrombolytic therapy is now the treatment of choice for patients with acute myocardial infarction and has been shown to reduce mortality ${ }^{12}$ and improve left ventricular function. ${ }^{3}$ However, not all patients treated wich thrombolytic therapy have successful reperfusion of the thrombosed artery and therapy is further limited by reocclusion and reinfarction in $10-25 \%$ of patients. ${ }^{4}$ The reasons for the resistance to lysis and the occurrence of reocclusion are unclear. Factors such as platelet activation associated with thrombolysis, ${ }^{56}$ and the procoagulant effects of plasmin ${ }^{7}$ probably contribute. In addition recent evidence suggests that the fibrinolytic system, and in particular plasminogen activator inhibitor (PAI-1), may be important. Both Sane et $a l^{8}$ and Barbash et $a l^{9}$ showed a relation between raised PAI-1 activity on admission with acute myocardial infarction and reduced likelihood of a patent infarct related artery after thrombolytic therapy with recombinant tissue plasminogen activator. Increased activity of PAI-1 has also been shown to predict the recurrence of infarction in young survivors of myocardial infarction. ${ }^{10}$

In diabetic patients mortality and morbidity from acute myocardial infarction are high. ${ }^{112}$ Non-insulin-dependent diabetic patients have previously been reported to have increased PAI-1 activity, ${ }^{13}{ }^{14}$ which may play a part in determining the outcome from myocardial infarction.

We studied admission levels of PAI-1 activity and outcome from thrombolytic therapy for acute myocardial infarction in 155 patients, both diabetic and non-diabetic, admitted to a district general hospital. The aims of this study were to determine whether (a) PAI-1 activity influences the response to thrombolytic therapy and (b) whether PAI-1 activity is higher in diabetic patients with acute myocardial infarction than in non-diabetic patients - a factor that might influence the outcome of thrombolytic therapy in diabetic patients.

\section{Patients and methods}

Over a two year period we studied 155 patients admitted with acute myocardial infarction to the Whittington Hospital. They accounted for $60 \%$ of all admissions with acute myocardial infarction over the period. Patients were excluded if an initial blood sample was not obtained before the administration of thrombolytic therapy, if they presented more than 24 hours after the onset of chest pain, or if myocardial infarction was not confirmed by World Health Organisation 
criteria. ${ }^{15}$ The proportion of diabetic patients was similar in those who were studied $(29 \%)$ and those who were excluded (25\%).

There were 45 diabetic patients. In 33 diabetes had already been diagnosed (median duration of diabetes $5(0 \cdot 5-25)$ years). Twelve cases of diabetes were newly diagnosed on the basis of admission hyperglycaemia (plasma glucose $\geqslant 11.0 \mathrm{mmol} / \mathrm{l}$ ) and increased glycated haemoglobin ${ }^{16}(\geqslant 8.5 \%$ measured by agar gel electrophoresis). At the time of admission 13 of the diabetic patients were treated by diet alone, 11 were treated with oral hypoglycaemic agents (eight a sulphonylurea, two metformin and one a combination of a sulphonylurea plus metformin) and nine were treated with insulin, of those nine, three were insulin dependent or ketosis prone. All were admitted within $24 \mathrm{~h}$ of the onset of chest pain and myocardial infarction was diagnosed according to World Health Organisation criteria. ${ }^{15}$

On admission to hospital and before thrombolytic therapy was given venous blood samples for estimation of PAI-1 activity and antigen and plasma fibrinogen were drawn from an antecubital vein through a $21 \mathrm{G}$ needle. PAI-1 activity and antigen were also measured on days 1,2 , and 3 between 0800 and $0830 \mathrm{~h}$ and on days 1 and 2 between 1700 and 1800 h. Blood samples were collected into tubes containing sodium citrate (nine parts of blood were mixed with one part of $3.8 \%$ sodium citrate), centrifuged for 15 min at $3000 \mathrm{~g}$ and $4^{\circ} \mathrm{C}$, and then stored at $-70^{\circ} \mathrm{C}$ until analysis. Creatine kinase $\mathrm{MB}$ isoenzyme was measured every $4 \mathrm{~h}$ for the first $24 \mathrm{~h}$, every $8 \mathrm{~h}$ for the next $24 \mathrm{~h}$, and every $12 \mathrm{~h}$ for the next $24 \mathrm{~h}$. The cumulative release of creatine kinase-MB isoenzyme was calculated by a modification ${ }^{17}$ of Sobel et al's methods ${ }^{18}$ according to the following equation:

Enzyme released $=E(T)+k d S_{0}{ }^{i} E(t) d t$ where $E(t)=$ enzyme level at time $t, t=$ time after onset of symptoms (hours), $\mathrm{T}=$ time of sample CK-MB concentration equals zero for the first time after peak sample CK-MB concentration has been achieved; otherwise $\mathrm{T}=$ time of last available sample; $\mathrm{kd}=$ dissociation constant $=0.095 \mathrm{IU} / \mathrm{h},{ }^{19}$ the area under the graph of $E(t), t_{0}{ }^{t} E(t) d t$, is approximated by

$$
\sum_{n_{i=1}} 1 / 2\left[E\left(t_{i}-1\right)+E\left(t_{i}\right)\right] \Delta t_{i}
$$

where $t_{0}=0, t_{1}, \ldots . ., t_{n}$ are the sampling times and $\mathrm{E}\left(\mathrm{t}_{0}\right)=0$ and $\Delta \mathrm{t}_{\mathrm{i}}=\mathrm{t}_{\mathrm{i}}-\mathrm{t}_{\mathrm{i}-1}$.

The time to peak release of creatine kinase$\mathrm{MB}$ isoenzyme release was calculated by plotting the creatine kinase-MB (IU/l) against time in hours. Time zero $(0 \mathrm{~h})$ was the time of onset of chest pain. We constructed time activity curves using a curve fitting procedure on a computer programme (Stat Graphics II) and we calculated the time to peak enzyme release for each patient. Reinfarction was defined as the recurrence of chest pain and electrocardiographic evidence of reinfarction in hospital in patients with enzymatic evidence of reperfusion after thrombolytic therapy.
To determine normal ranges of PAI-1 activity and antigen in diabetic and non-diabetic patients without ischaemic heart disease we took venous blood samples without stasis between 0830 and 0930 in 15 diabetic and 20 non-diabetic individuals with no clinical or electrocardiographic evidence of ischaemic heart disease or hypertension.

ASSAYS

Plasma glucose was measured by a glucose oxidase method (Beckman, Brea, CA, USA). Glycated haemoglobin was measured by agar gel electrophoresis (Corning Medical, Halstead, Essex). PAI-1 activity was measured by a chromogenic assay (Kabi Diagnostica, Molndal, Sweden. ${ }^{20}$ In this assay a fixed amount of tissue plasminogen activator ( $t-P A)$ is added in excess to undiluted plasma and forms an inactive complex with PAI-1. Plasminogen is then activated to plasmin by residual t-PA in the presence of a stimulator. The amount of plasmin is directly proportional to the residual t-PA activity and inversely proportional to the PAI-1 activity of the sample. The amount of plasmin is determined by measuring the amidolytic activity of plasmin on the chromogenic substrate $S$ 2403. The intra-assay coefficient of variation (cv) was $4.5 \%$ and the inter-assay cv was $8 \%$. PAI-1 antigen was measured by an enzyme linked immunosorbent assay (Biopool AB, Umea, Sweden). This assay quantifies active, latent, and complexed human endothelial type PAI- $1 .^{21}$ The within assay cv was $4.5 \%$ and the between assay $\mathrm{cv}$ was $7 \cdot 5 \%$. Plasma fibrinogen was measured according to the Clauss method ${ }^{22}$ Boehringer Mannheim Diagnostica, Meylan, France). Creatine kinase-MB isoenzyme was measured by an immunological method (Boehringer Mannheim Diagnostica, Meylan, France).

\section{STATISTICAL ANALYSIS}

Results are expressed as mean (SD) for normally distributed data and median and range for skewed data. Differences between groups were tested by unpaired Student's $t$ tests for normally distributed data and Mann-Whitney $\mathrm{U}$ tests for skewed data. Within group differences were tested by paired Student's $t$ tests for normally distributed data and Wilcoxon rank tests for skewed data. Relations between variables were assessed by Pearson's correlation for normally distributed data and Spearman rank correlation for skewed data. Differences between proportions were assessed by $\chi^{2}$ analysis. Multiple regression analysis was used to study the independent relation between variables after logarithmic transformation of skewed data. A $p$ value $<0.05$ was regarded as significant.

\section{Results}

Table 1 shows the characteristics of the patients. Diabetic and non-diabetic patients were comparable in age, site of infarction, the proportion with a history of previous myocardial infarction, the proportion receiving 
Table 1 Characteristics of diabetic and non-diabetic patients admitted with acute myocardial infarction*

\begin{tabular}{|c|c|c|c|}
\hline \multirow{2}{*}{$\begin{array}{l} \\
\text { Age (years) } \\
\text { Sex (M:F) }\end{array}$} & \multirow{2}{*}{$\begin{array}{l}\text { Diabetic }(n=45) \\
\begin{array}{l}64 \cdot 2(9 \cdot 2) \\
33: 12\end{array}\end{array}$} & \multicolumn{2}{|c|}{ Non-diabetic $(n=110)$} \\
\hline & & $\begin{array}{l}64 \cdot 7(12 \cdot 4) \\
74: 36\end{array}$ & $\begin{array}{l}\text { NS } \\
\text { NS }\end{array}$ \\
\hline Site of infarction: & & & \\
\hline $\begin{array}{l}\text { Anterior } \\
\text { Inferior }\end{array}$ & $\begin{array}{l}48 \cdot 9 \% \\
35 \cdot 6 \%\end{array}$ & $\begin{array}{l}43 \cdot 6 \% \\
41 \cdot 8 \%\end{array}$ & NS \\
\hline$\%$ with previous myocardial infarction & $26 \cdot 7 \%$ & $20.9 \%$ & NS \\
\hline $\begin{array}{l}\text { Time from onset chest pain to thrombolytic } \\
\text { therapy (hours) }\end{array}$ & $5(2-18)$ & $4(0.5-22)$ & NS \\
\hline $\begin{array}{l}\text { CK-MB cumulative release (IU/I) } \\
\text { Peak AST (IU/I) }\end{array}$ & $\begin{array}{l}191(52-572) \\
181(17-543)\end{array}$ & $\begin{array}{l}227(46-839) \\
210(25-865)\end{array}$ & $\begin{array}{l}\text { NS } \\
\text { NS }\end{array}$ \\
\hline $\begin{array}{l}\text { Time to peak CK-MB release after } \\
\text { thrombolysis }(\mathrm{h}) t\end{array}$ & $15 \cdot 5(7 \cdot 5-24)$ & $12(5-26)$ & 0.005 \\
\hline Time to peak CK-MB release without & & & \\
\hline $\begin{array}{l}\text { thrombolysis }(\mathrm{h}) \ddagger \\
\% \text { Receiving thrombolytic therapy } \\
\text { Admission plasma glucose }(\mathrm{mmol} / \mathrm{l}) \\
\text { Glycated haemoglobin }(\%)\end{array}$ & $\begin{array}{l}17(10 \text { to } 24) \\
68 \cdot 9 \%(31 / 45) \\
15 \cdot 7(6-43 \cdot 6) \\
10 \cdot 2(2 \cdot 0)\end{array}$ & $\begin{array}{l}19(6-24) \\
79 \cdot 1 \%(87 / 110) \\
8 \cdot 4(5 \cdot 1-17 \cdot 6) \\
7 \cdot 2(0 \cdot 7)\end{array}$ & $\begin{array}{l}\text { NS } \\
\text { NS } \\
0.0001 \\
0.0001\end{array}$ \\
\hline Newly diagnosed diabetes & $12(26 \cdot 6 \%)$ & - & - \\
\hline Duration of known diabetes (years) & $5(0 \cdot 5-15)$ & - & - \\
\hline Treatment for diabetes: & & & \\
\hline $\begin{array}{l}\text { Diet } \\
\text { Oral hypoglycaemic } \\
\text { Insulin }\end{array}$ & $\begin{array}{r}13(39 \cdot 4 \%) \\
11(33.3 \%) \\
9(27 \cdot 3 \%)\end{array}$ & - & - \\
\hline
\end{tabular}

*Values are mean (SD) for normally distributed data and median (range) for skewed data, CK, creatine kinase; AST, aspartate aminotransferase.

tIn 98 patients who received thrombolysis. $\neq$ In 25 patients who did not receive thrombolysis.

thrombolytic therapy, time from onset of symptoms to receiving thrombolytic therapy, and infarct size as assessed by cumulative release of creatine kinase-MB isoenzyme. In patients receiving thrombolytic therapy the time to peak creatine kinase-MB enzyme release was significantly prolonged in diabetic patients than in non-diabetic patients.

Admission values for both PAI-1 activity and antigen were significantly higher in diabetic patients than in non-diabetic patients and in both these groups compared with controls (table 2). The distribution of admission sample time was not significantly different in the diabetic and non-diabetic groups. As we have previously shown ${ }^{23}$ there were no differences in PAI-1 activity or antigen concentrations between those patients with previously known or newly diagnosed diabetes $(p=0.49$ and 0.90 respectively) or between those treated with insulin, oral hypoglycaemic agents, or diet alone $(p=0.89$ and 0.22 respectively). There was a positive correlation between PAI-1 activity and antigen $(r=0.50$; $p=0.0001$ ) in those admitted with acute myocardial infarction. One hundred and eighteen patients (87 non diabetic and 31 diabetic) received thrombolytic therapy. During the period of this study our hospital was participating in a randomised study of thrombolytic agents in acute myocardial infarction (ISIS III) and consequently the thrombolytic agents used were streptokinase in 75 ( 55 non-diabetic and 20 diabetic), anistreplase in 19 (13 non-diabetic and six diabetic), and alteplase (rt-PA) in 24 (19 non diabetic and five diabetic). Figures 1 and 2 show PAI-1 activity after admission. In patients who received thrombolytic therapy PAI-1 activity increased significantly on day 1 and fell towards admission values on days 2 and 3 (fig 1A). In those not receiving thrombolytic therapy PAI-1 activity also increased on day 1 but this was only significant in the diabetic patients (figure 1B). The trend in PAI-1 antigen concentration was similar but was significant only in the non-diabetic patients receiving thrombolytic therapy and diabetic patients not receiving thrombolytic therapy (figs $2 \mathrm{~A}$ and $\mathrm{B}$ ).

It was possible to calculate time to peak creatine kinase-MB isoenzyme release in 124 patients of whom 98 (72 non-diabetic (57 streptokinase or anistreplase and 15 alteplase) and 26 diabetic (21 streptokinase or anistreplase and five alteplase) received thrombolytic therapy. In the remaining 31 patients it was not possible to calculate time to peak enzyme release because insufficient samples were available in 24 and seven died within $24 \mathrm{~h}$ of admission. There was a significant positive correlation between the median time from onset of chest pain and the time to peak enzyme release $\left(r_{s}=0.42 ; p=0.0001\right)$, but there was no difference between the median time from onset of chest pain to administration of thrombolytic therapy in the two groups (4 h (0.5-22) in non-diabetic patients compared with $5 \mathrm{~h}(2$ to 18$)$ in diabetic subjects). There was no difference in time to peak enzyme release between those with a history of previous infarction and those without (13.5 (6-22) h v 13 (5-26) h). Among those receiving thrombolytic therapy diabetic patients had a significantly longer time to peak enzyme release than non-diabetic patients (table 1 and fig 3). When we took a cut off of time to peak of $\leqslant 12 \mathrm{~h}$ as indicating likely successful reperfusion, ${ }^{24-26} 65 \%(47 / 72)$ of the non-diabetic patients showed evidence of reperfusion compared with $23 \%(6 / 26)$ of the diabetic patients $\left(\chi^{2}=13.4,1 \mathrm{df}\right.$; $p<0.001)$. There was enzymatic evidence of reperfusion in $55 \%$ of those receiving streptokinase or anistreplase and in $50 \%$ of those receiving alteplase (NS). There was no difference in time to peak enzyme release between non-diabetic and diabetic patients not receiving thrombolytic therapy $(19(6-24)(n=17)$ $v 17(10-24)(n=8)$ with only $12 \%(2 / 17)$ of non-diabetic and $25 \%(2 / 8)$ of diabetic patients showing enzymatic evidence of reper-

Table 2 PAI-1 activity and PAI-1 antigen in diabetic and non-diabetic patients at admission with acute myocardial infarction and in controls

\begin{tabular}{|c|c|c|c|c|c|c|}
\hline & \multicolumn{3}{|l|}{ Diabetic } & \multicolumn{3}{|l|}{ Non diabetic } \\
\hline & Patients $(n=45)$ & Controls $(n=15)$ & $p$ & Patients $(n=110)$ & Controls $(n=20)$ & $p$ \\
\hline $\begin{array}{l}\text { PAI-1 activity (AU/ml) } \\
\text { PAI-1 antigen (ng/ml) } \\
\text { Fibrinogen (mg/dl) }\end{array}$ & $\begin{array}{l}24.6(6 \cdot 9) \\
58 \cdot 8(13 \cdot 1-328 \cdot 8) \\
298(95-794)\end{array}$ & $\begin{array}{l}18 \cdot 7(5 \cdot 6) \\
24 \cdot 3(9 \cdot 8-41 \cdot 1)\end{array}$ & $\begin{array}{l}0.0001 \\
0.0001 \\
\end{array}$ & $\begin{array}{l}18 \cdot 6(7 \cdot 9)^{\star} \\
41 \cdot 0(10 \cdot 9-215 \cdot 4) \dagger \\
266(139 \text { to } 525) \ddagger\end{array}$ & $\begin{array}{l}12 \cdot 0(3 \cdot 8) \\
19 \cdot 9(4 \cdot 5-52 \cdot 7)\end{array}$ & $\begin{array}{l}0.0001 \\
0.0001 \\
-\end{array}$ \\
\hline
\end{tabular}

Values are mean (SD) for normally distributed data and median and range for skewed data PAI-1, plasminogen activato inhibitor; $A U$, arbitrary unit. ${ }^{\star} p=0.0001 ; \mathrm{tp}=0.004$, and $\mathrm{fp}=0.004$ for diabetic $v$ non-diabetic patients with acute myocardial infarction. 

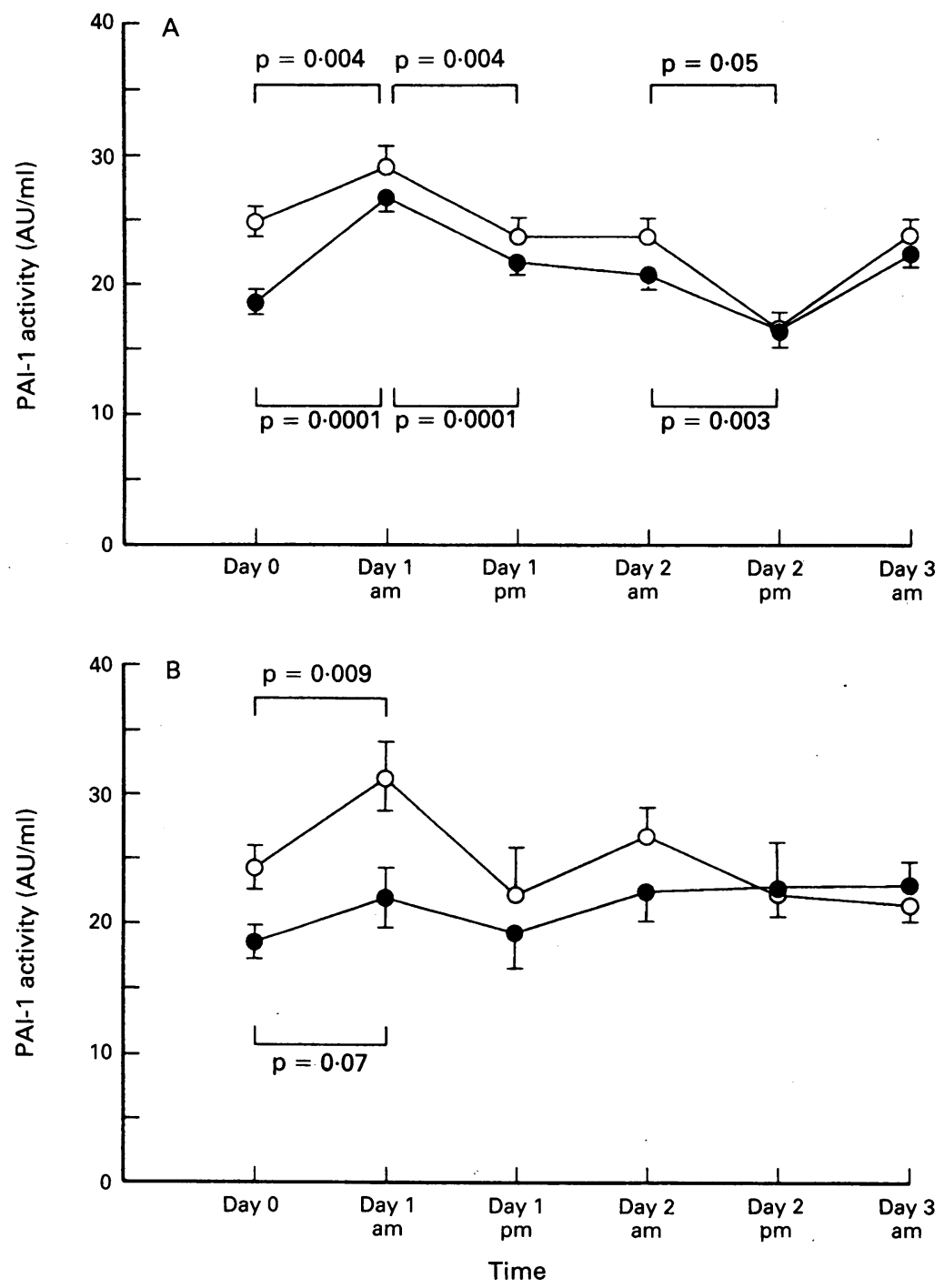

Figure 1 (A) PAI-1 activity after acute myocardial infarction in diabetic $(O)$ and non-diabetic (O) patients given thrombolytic agents. (B) PAI-1 activity after acute myocardial infarction in diabetic $(O)$ and non-diabetic $(O)$ patients treated with thrombolytic agents. sensitivity of $93 \%$ and a specificity of $100 \%$ in estimating reperfusion, ${ }^{27}$ we repeated the analysis with $16.5 \mathrm{~h}$ as the cut off for reperfusion. PAI-1 activity was still significantly lower in those with enzymatic evidence of reperfusion $(19.0(8 \cdot 1) v 22.8(7.5) \mathrm{AU} / \mathrm{ml}, \mathrm{p}$ $=0.04)$ and in multiple regression analysis admission PAI-1 activity was still a significant determinant of reperfusion ( $p=0.04$ for PAI1 activity and $p=0.05$ for diabetes).

Table 3 shows PAI-1 activity in patients with evidence of reinfarction after thrombolytic therapy. Though values were not significantly different on admission or days 1 and 2 they were significantly higher on day 3 than in those without evidence of reinfarction. Thirteen patients (nine non-diabetic and four diabetic) had evidence of reinfarction. Seven had been treated with streptokinase, four anistreplase, and two alteplase.

PAI-1 antigen concentrations showed similar trends as activity, being lower on admission in patients with enzymatic evidence of reperfusion than in those without evidence of reperfusion (39.9 (14.8-111.8) $v$ $53.5(15 \cdot 8-328 \cdot 8) \mathrm{ng} / \mathrm{ml}, \mathrm{p}=0 \cdot 049)$. No significant difference was observed, however, between concentrations of PAI-1 antigen on day 3 in patients with and without evidence of reinfarction in hospital $(40.9(17 \cdot 3-85 \cdot 1) v$ $36 \cdot 1(11 \cdot 0-161 \cdot 0) \mathrm{ng} / \mathrm{ml})$.

Table 2 shows plasma fibrinogen concentrations at admission. In those who were treated with thrombolytic agents there was no significant difference in fibrinogen concentrations between those with successful reperfusion and those without (252 (139-492) $v 266$ $(95445) \mathrm{mg} / \mathrm{dl}$ ) or in those with evidence of reinfarction compared with those without (280 (168-362) v $266(95-794) \mathrm{mg} / \mathrm{dl})$.

\section{Discussion}

We confirmed our previous finding that PAI1 activity on admission with acute myocardial infarction was significantly higher in diabetic patients than in non-diabetic ones. ${ }^{27} \mathrm{We}$ also found that increased PAI-1 activity was associated with both enzymatic evidence of failure of reperfusion after thrombolytic therapy and the likelihood of in hospital reinfarction. These findings therefore suggest that a high baseline PAI-1 activity may indicate unsuccessful thrombolysis not only with alteplase but also with other thrombolytic agents $(80 \%$ of our patients received streptokinase or anistreplase).

We found that the diabetic patients were significantly less likely to show enzymatic evidence of reperfusion after thrombolytic therapy and that this was associated with high values of PAI-1 activity at admission. In view of our finding that diabetic patients with acute myocardial infarction had significantly higher baseline PAI-1 values than the nondiabetic patients, it is tempting to speculate that raised circulating PAI-1 concentrations, either directly or by reflecting high PAI-1 activity in the region of the thrombus, may in some way unfavourably alter the balance reperfusion and persistent occlusion. 24-26 However, in the light of a recent report that a time to peak release of creatine kinase-MB isoenzyme $<16.5 \mathrm{~h}$ corresponded to a 

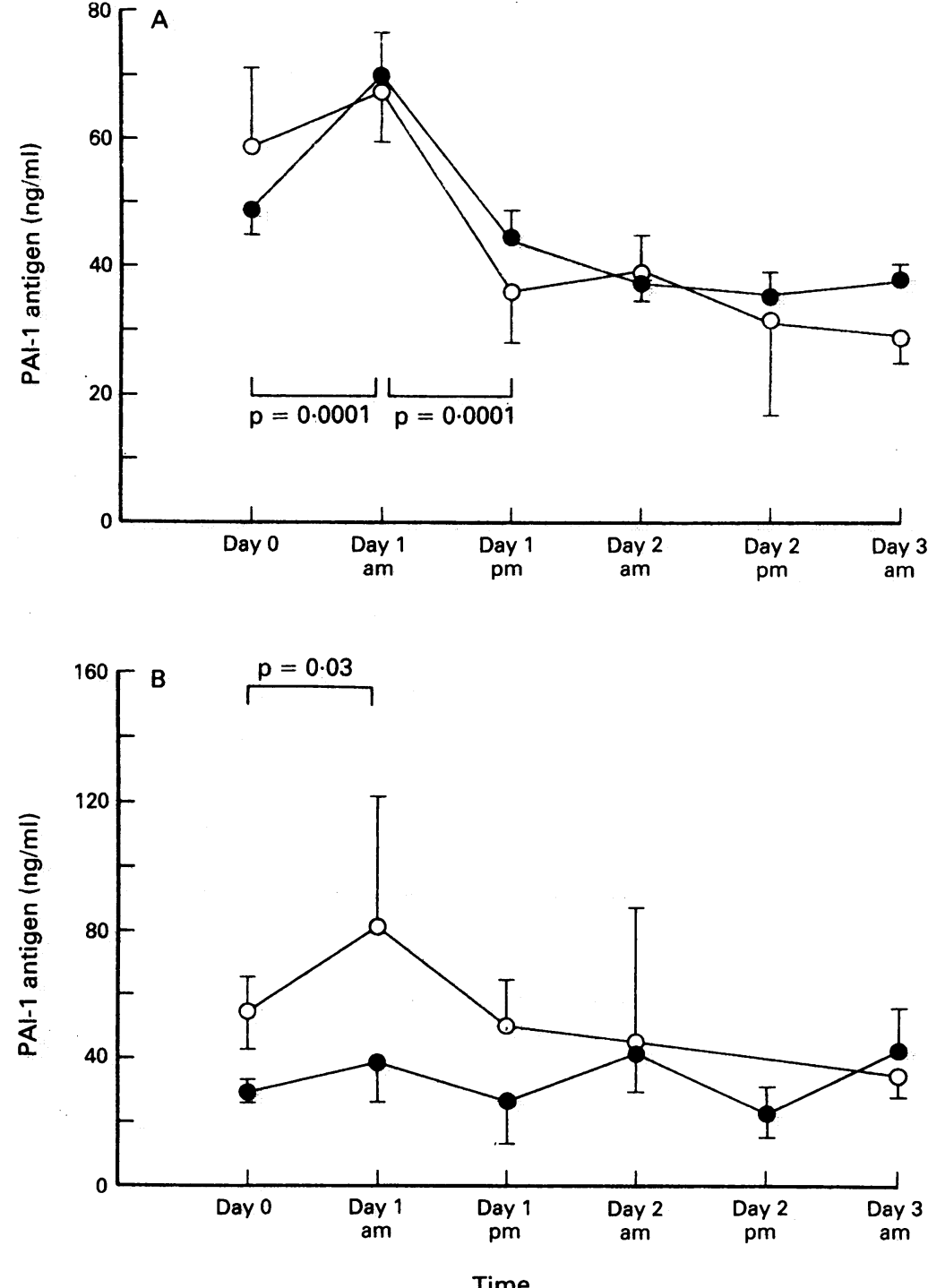

Figure 2 (A) PAI-1 antigen after acute myocardial infarction in diabetic $(O)$ and non-diabetic (O) patients treated with thrombolytic agents. (B) PAI-1 antigen after acute myocardial infarction in diabetic $(O)$ and non-diabetic (O) patients not treated with thrombolytic agents.

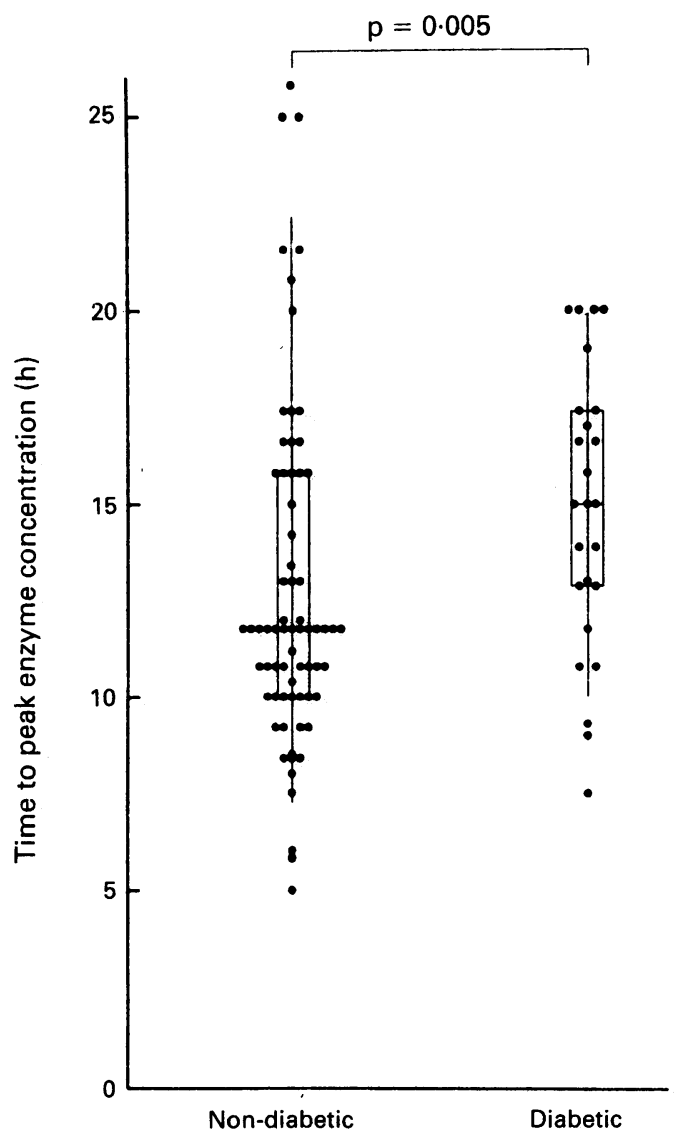

Figure 3 Time to peak creatine kinase-MB isoenzyme release in diabetic and non-diabetic patients treated with thrombolytic agents (calculated from time of onset of symptoms). The box encloses the 25th to 75th centiles and the 10th and 90th centiles are also indicated.

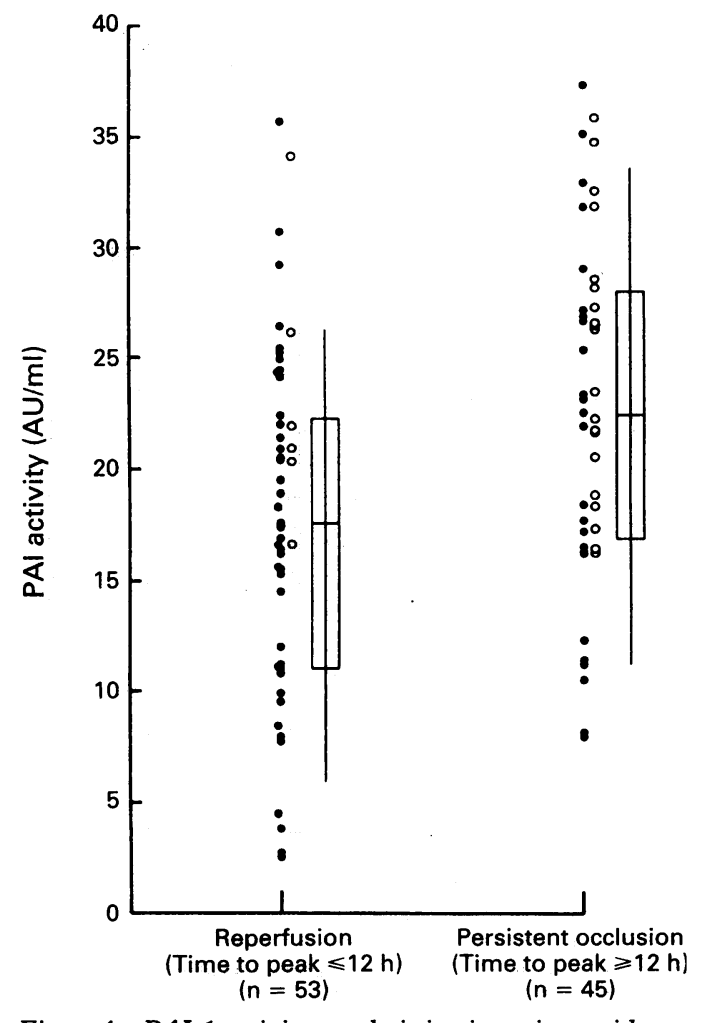

Figure 4 PAI-1 activity at admission in patients with acute myocardial infarction with successful and unsuccessful reperfusion. (O) Diabetic and (O) nondiabetic patients. The box encloses the 25th to 75th centiles and the 10th and 90th centiles are also indicated. 
Table 3 Multiple regression analysis for determinants of reperfusion in subjects receiving thrombolytic therapy

\begin{tabular}{|c|c|c|c|c|}
\hline Variable in model & Variable added & $F$ change & Multiple $r^{2}$ & Significance \\
\hline $\begin{array}{l}\text { Diabetes } \\
\text { Diabetes, admission PAI-1 activity } \\
\text { Diabetes, admission PAI-1 activity, TFOS }\end{array}$ & $\begin{array}{l}\text { Diabetes } \\
\text { Admission PAI-1 activity } \\
\text { TFOS } \\
\text { Thrombolytic agent }\end{array}$ & $\begin{array}{c}15 \cdot 6 \\
4 \cdot 92 \\
12 \cdot 2 \\
0 \cdot 009\end{array}$ & $\begin{array}{l}0 \cdot 14 \\
0 \cdot 18 \\
0 \cdot 28 \\
0 \cdot 28\end{array}$ & $\begin{array}{l}0.000 \\
0.029 \\
0.001 \\
0.924\end{array}$ \\
\hline
\end{tabular}

TFOS, time from onset of chest pain to administration of thrombolytic therapy.

treatment protocols in the average patient PAI-1 activity will be overwhelmed by an excess of thrombolytic agent. Streptokinase and anistreplase activate the fibrinolytic system indirectly by forming a complex with plasminogen, which converts the inactive proenzyme and enzyme into effective plasminogen activators that are not affected by PAI-1 activity. Rather than having a direct effect on the thrombolytic treatment itself, high circulating PAI-1 activity may be a marker for local effects of PAI-1. High PAI-1 activity when the initial thrombus forms may hamper the natural fibrinolytic process, resulting in a more stable thrombus that is resistant to lysis. Furthermore, thrombus containing a large number of platelets rich in PAI- ${ }^{31}$ would be less vulnerable to lysis by thrombolytic therapy. Thrombi may be enriched in PAI-1 by platelets, which contain up to $85 \%$ of the PAI-1 in platelet rich plasma, ${ }^{32}$ and this may account at least in part for the observed resistance of platelet rich thrombi to dissolution by alteplase compared with erythrocyte rich thrombi. ${ }^{33}$ Moreover, in animal studies both circulating and clot bound PAI-1 have been shown to inhibit fibrinolysis, suggesting that PAI-1 within a thrombus provides an important thrombus stabilizing effect. ${ }^{34}$ PAI-1 synthesis and release at the site of injury or thrombus formation by vascular endothelial cells and smooth muscle cells may be the important factors in the regulation and control of fibrinolysis and circulating concentrations may reflect such activity locally.

In addition to a possible role in determining the balance between reperfusion and early reocclusion after thrombolytic therapy, PAI-1 activity may be an important determinant of rethrombosis and reinfarction, which can occur in $10-25 \%$ of patients. ${ }^{4}$ Increased PAI1 activity has been shown to predict recurrent infarction in young survivors of myocardial infarction over a 3 year follow up. ${ }^{10}$ However, whether PAI-1 concentrations play a part in determining early rethrombosis and reinfarction is still not clear. Sane et al found no correlation between baseline PAI-1 concentrations and the risk of reocclusion ${ }^{8}$ and

Table 4 PAI-1 activity $(A U / m l)$ in subjects with and without evidence of reinfarction

\begin{tabular}{llll}
\hline$P A I-1$ & $\begin{array}{l}\text { Reinfarction } \\
(n=13)\end{array}$ & $\begin{array}{l}\text { No reinfarction } \\
(n=85)\end{array}$ \\
\hline On admission & $20 \cdot 6(11 \cdot 0)$ & $20 \cdot 1(7 \cdot 9)$ & NS \\
Day 1 & $25 \cdot 0(10 \cdot 1)$ & $27 \cdot 4(7.4)$ & NS \\
Day 2 & $24 \cdot 6(8 \cdot 0)$ & $20 \cdot 7(6.9)$ & NS \\
Day 3 & $26.7(6.4)$ & $21 \cdot 7(6.3)$ & 0.032 \\
\hline
\end{tabular}

Values are mean (SD).

PAI-1, plasminogen activator inhibitor; AU, arbitrary unit.
Rapold et al found no difference in PAI-1 concentrations measured up to 24 hours after acute myocardial infarction between patients with and without clinical evidence of reocclusion. ${ }^{35}$ Lucore et al showed that after infusion of alteplase, tissue plasminogen activator concentrations 7 -fold greater than baseline were effectively neutralised by $\mathrm{PAI}-1,{ }^{3637}$ suggesting that PAI-1 activity after the infusion of thrombolytic therapy might influence the occurrence of reocclusion after initial successful reperfusion. Though like others we found no relation between baseline PAI-1 concentrations and the occurrence of reinfarction, PAI-1 activity on day 3 was significantly higher in patients with clinical evidence of reinfarction than in those without evidence of reinfarction.

In view of these findings suggesting that increased PAI-1 activity may influence the outcome of thrombolytic therapy, an important question is whether increased PAI-1 activity can be influenced by treatment. In non-diabetic sedentary patients cessation of smoking, physical training, and weight reduction were associated with a reduction in PAI1 concentrations. ${ }^{38}$ In addition to its effects on blood glucose metabolism metformin has recently been shown to have favourable effects on fibrinolysis, lipid metabolism, and blood pressure. ${ }^{3940}$ However, more long-term studies will be required to evaluate the clinical significance of these findings. Another important consideration is whether those with raised PAI-1 activity on admission with acute myocardial infarction and in particular diabetic patients require higher doses or continuous infusions of thrombolytic agent to achieve successful reperfusion. It is important, however, to recognise the limitations of this study. While an early time to peak creatine kinase-MB isoenzyme release has been shown to be a valid index of reperfusion it is not specific and it is therefore possible that we are misclassifying some patients by this method. Early time to peak enzyme release has also been seen in patients with subtotal occlusion, ${ }^{26}$ patients with well developed collateral flow to the infarct zone, ${ }^{41}$ and in those with early spontaneous reperfusion..$^{42}$ Another limitation of the prediction of reperfusion based on time to peak analysis is that its discriminating power depends on the duration of the ischaemic period before reperfusion because the peak value might be missed if this interval is prolonged. In addition, it was not possible to calculate time to peak enzyme release in $20 \%$ of the patients. Furthermore, the finding of similar reperfusion rates with alteplase and streptokinase in this study does not accord with other studies. However, 
when we repeated the analysis with another criterion of reperfusion we found similar results. Moreover, any misclassification would be likely to weaken any relation between PAI-1 and reperfusion. The findings in this study need to be confirmed with a more sensitive index of reperfusion such as early coronary angiography.

We found that diabetic patients had less enzymatic evidence of reperfusion and raised PAI-1 activity on admission with acute myocardial infarction than non-diabetic patients. In multiple regression analysis both admission PAI-1 activity and diabetes were independently related to reperfusion. Therefore the raised PAI-1 activity in diabetic patients compared with non-diabetic patients might in part explain the poor outcome of diabetic patients after myocardial infarction. However, PAI-1 and fibrinogen were the only variables measured and other fibrinolytic variables that were not measured in this study could produce similar effects.

1 Gruppo Italiano Per Lo Studio Della Streptochinasi Nell 'Infarcto Miocardico (GISSI): long term effects of intravenous thrombolysis in acute myocardial infarction. venous thrombolysis in acute myocardial infarction.

2 ISIS-2 Collaborative Group. Randomised trial of intravenous streptokinase, oral aspirin or both or neither among 17187 cases of suspected acu

3 White HD, Norris RM, Brown MA, Takayama M, Maslowski A, Bass NM, Ormiston JA, Whitlock T. Effect of intravenous streptokinase on left ventricula function and early survival after myocardial infarction. $N$ Engl ₹ Med 1987;317:850-5.

4 TIMI Study Group. Thrombolysis in Myocardial Infarction trial (TIMI), phase 1: a comparison between intravenous tissue plasminogen activator and intravenous streptokinase. Circulation 1987;76:142-54.

5 Kerins DM, Roy L, FitzGerald GA, Fitzgerald DJ. Platelet and vascular function during coronary thrombolysis with tissue type plasminogen activator. Circulation 1989;80:1718-25.

6 Fizzerald DJ, Catella F, Roy L, FitzGerald GA. Marked platelet activation in vivo after intravenous streptokinase in patients with

7 Eisenberg PR, Sherman LA, Jaffe AS. Paradoxic elevation of fibrinopeptide A after streptokinase: Evidence of continued thrombosis despite imtense fibrinolysis. $\mathrm{f} \mathrm{Am} \mathrm{Coll}$ Cardiol 1987;10:527-9.

8 Sane DC, Stump DC, Topol EJ, Sigmon KN, Kereiakes DJ, George BS, et al. Correlation between baseline plasminogen activator inhibitor levels and clinical outcome during therapy with tissue plasminogen activator for acute myocardial infarction. Thromb Haemost 1991;65: 275-9.

9 Barbash GI, Hod H, Roth A, Miller HI, Rath S, Har Zahav Y, et al. Correlation of baseline plasminogen activator inhibitor activity with patency of the infarct related artery after thrombolytic therapy in acute myocardial infarction. Am 7 Cardiol 1989;64:1231-5.

10 Hamsten A, de Faire U, Walldius G, Dahlen G, Szamosi $A$, Landou $C$ et al. Plasminogen activator inhibitor in plasma: risk factor for recurrent myocardial infarction. Lancet 1987;1:3-8.

11 Yudkin JS, Oswald GA. Determinants of hospital admis sion and case fatality in diabetic patients with myocarsion and case fatality in diabetic patients with

12 Gwilt DJ. Why do diabetic patients die after myocardial infarction. Practical Diabetes 1984;1:36-9.

13 Juhan-Vague I, Roul C, Alessi MC, Ardissone JP, Heim $\mathbf{M}$, Vague $\mathbf{P}$. Increased plasminogen activator inhibitor in non insulin dependent diabetes-relationship with plasma insulin. Thromb Haemost 1989;61:370-3.

14 Auwerx J, Bouillon R, Collen D, Geboers J. Tissue plasminogen activator antigen and plasminogen activato inhibitor in diabetes mellitus. Atherosclerosis 1988;8: 68-72.

15 WHO regional office for Europe. Public health in Europe 5. Myocardial infarction community registers. Annex 1, Copenhagen 1976

16 Oswald GA, Yudkin JS. Hyperglycaemia following acute myocardial infarction: the contribution of undiagnosed diabetes. Diabetic Med 1987;4:68-70.

17 McC Boyle D, Barber JM, McIlmoyle EL, Salathia KS
Evans AE, Cran G, et al. Effect of very early intervenion with metaprolol on myocardial infarct size. $\mathrm{Br}$ Heart 1983;49:229-33.

18 Sobel BE, Bresnahan GF, Shell WE, Yoder RD. Estimation of infarct size in man and its relation to prognosis. Circulation 1972;46:640-8.

19 Grande P, Naestoft J, Christiansen C. An easy and reliable estimation of acute myocardial infarct size from serum CK-MB measurements. Eur $f$ Cardiol 1980;11:71-7.

20 Chmielewska J, Rånby $M$, Wiman B. Evidence for a rapid inhibitor to tissue plasminogen activator in plasma. Thromb Res 1983;31:427-36.

21 Declerck PJ, Alessi MC, Verstreken M, Kruithof EKO, Juhan-Vague I, Collen D. Measurement of plasminogen activator inhibitor 1 in biological fluids with a murine monoclonal antibody based enzyme linked immunosormonoclonal antibody based enzym

22 Clauss A. Rapid physiological coagulation method in determination of fibrinogen. Acta Haematol 1957;17: 237.

23 Gray RP, Yudkin JS, Patterson DLP. Plasminogen activator inhibitor: a risk factor for myocardial infarction in diabetic patients. Br Heart f 1993;69:228-32.

24 Gore JM, Roberts R, Ball SP, Montero A, Goldberg RJ, Dalen DE. Peak creatine kinase as a measure of effectiveness of thrombolytic therapy in acute myocardial infarction. Am ₹ Cardiol 1987;59:1234-8.

25 Katus HA, Diederich KW, Scheffold T, Uellner M, Schwarz F, Kubler W. Non invasive assessment of infarct reperfusion: the predictive power of the time to peak value of myoglobin, $\mathrm{CKMB}$, and $\mathrm{CK}$ in serum. Eur Heart $\mathcal{F}$ 1988;9:619-24.

26 Schroder R, Biamino G, Leitner ER, Linderer $T$, Bruggemann $\mathrm{T}$, Heitz $\mathrm{J}$, et al. Intravenous short term infusion of streptokinase in acute myocardial infarction. Circulation 1983;67:536-48.

27 Grande P, Granborg J, Clemmensen P, Sevilla DC, Wagner NB, Wagner GS. Indices of reperfusion in patients with acute myocardial infarction using characpatients with acute myocardial infarction using charac1991;122:400-408.

28 Kwann HC, Colwell JA, Cruz S, Suwanwela N, Dobbie JG. Increased platelet aggregation in diabetes mellitus. $\mathcal{F}$ Lab Clin Med 1972;80:236-46.

29 Hendra TJ, Yudkin JS. "Spontaneous" platelet aggregation in whole blood in diabetics with and without microvascular disease. Diabetic Med 1992;9:246-51.

30 Fuller JH, Keen H, Jarrett RJ, Omer T, Meade TW, Chakrabarti $R$, et al. Haemostatic variables associated with diabetes and its complications. $B r M e d \mathcal{F} 1979 ; 2$ : 964-6.

31 Kruithof EKO, Tran Thang C, Bachmann F. Studies on the release of plasminogen activator inhibitor by human platelets. Thromb Haemost 1985;55:201-5.

32 Kruithof EKO, Nicolosa G, Bachmann F. Plasminogen activator inhibitor 1 : development of a radioimmunoassay and observations on its plasma concentration during venous occlusion and after platelet aggregation. Blood venous occlusion

33 Jang IK, Gold HK, Ziskind AA, Fallon JT, Holt RE, Leinbach RC, et al. Differential sensitivity of erythrocyte Leinbach RC, et al. Differential sensitivity of erythrocyte rich and platelet rich arterial thrombi to lysis with recombinant tissue type

34 Reilly CF, Fujita T, Mayer EJ, Siegfried ME. Both circulating and clot bound plasminogen activator inhibitor-1 inhibit endogenous fibrinolysis in the rat. Arteriosc Thromb 1991;11:1276-86.

35 Rapold HJ, Grimaudo V, Declerck PJ, Kruithof EKO, Bachmann F. Plasma levels of plasminogen activator inhibitor type $1, \beta$-thromboglobulin, and fibrinopeptide $A$ before, during, and after treatment of acute myocardial infarction with alteplase. Blood 1991;78:1490-95.

36 Lucore CL, Sobel BE. Interactions of tissue type plasminogen activator with plasma inhibitors and their pharmacologic implications. Circulation 1988;77:660-69.

37 Lucore CL, Fujii S, Sobel BE. Dependence of fibrinolytic activity on the concentration of free rather than total tissue-type plasminogen activator in plasma after pharmacologic administration. Circulation 1989;79:1204-13.

38 Gris JC, Schved JF, Feugeas O, Agailar-Martinez P, Arnaud A, Sanchez N, Sarlat C. Impact of smoking, physical training and weight reduction on FVII, PAI-1 physical training and weight reduction on FVII, PAI-1 Haemost 1990;64:516-20.

39 Vague P, Juhan-Vague I, Alessi MC, Badier C, Valadier J. Metformin decreases the high plasminogen activator inhibitor capacity, plasma insulin and triglyceride levels in non diabeti

40 Grant PJ, Stickland MH, Booth NA, Prentice CRM. Metformin causes a reduction in basal and post venous occlusion plasminogen activator inhibitor in type 2 diabetic patients. Diabetic Med 1991;8:361-65.

41 Schwartz H, Leiboff RI, Katz RJ, Wassermann AG, Bren GB, Varghese PJ, Ross AM. Arteriographic predictors of spontaneous improvement in left ventricular function after myocardial infarction. Circulation 1985;71:466-72.

42 Ong L, Reiser P, Coromilas J, Scherr L, Morrison J. Left ventricular function and rapid release of creatine kinase $\mathrm{MB}$ in acute myocardial infarction. $N$ Engl $\mathcal{F} \mathrm{Med} 1983$ 309:1-6. 